\title{
Cytotoxic and pro-apoptotic action of MjTX-I, a phospholipase A2 isolated from Bothrops moojeni snake venom, towards leukemic cells
}

\author{
Rogério Bodini Benati, Tássia Rafaela Costa, Maira da Costa Cacemiro, Suely Vilela Sampaio,
}

Fabíola Attié de Castro and Sandra Mara Burin ${ }^{*}$

\begin{abstract}
Background: Chronic myeloid leukemia (CML) is a BCR-ABL1+ myeloproliferative neoplasm marked by increased myeloproliferation and presence of leukemic cells resistant to apoptosis. The current first-line therapy for CML is administration of the tyrosine kinase inhibitors imatinib mesylate, dasatinib or nilotinib. Although effective to treat $\mathrm{CML}$, some patients have become resistant to this therapy, leading to disease progression and death. Thus, the discovery of new compounds to improve CML therapy is still challenging. Here we addressed whether MjTX-I, a phospholipase $A_{2}$ isolated from Bothrops moojeni snake venom, affects the viability of imatinib mesylate-resistant $\mathrm{Bcr}-\mathrm{Abl}^{+}$cell lines.

Methods: We examined the cytotoxic and pro-apoptotic effect of MjTX-I in K562-S and K562-R Bcr-Abl ${ }^{+}$cells and in the non-tumor HEK-293 cell line and peripheral blood mononuclear cells, using the 3-(4,5-dimethylthiazol-2-yl) -2,5-diphenyltetrazolium bromide and the hypotonic fluorescent solution methods, associated with detection of caspases 3, 8, and 9 activation and poly (ADP-ribose) polymerase (PARP) cleavage. We also analyzed the MjTX-I potential to modulate the expression of apoptosis-related genes in K562-S and K562-R cells.

Results: MjTX-I decreased the viability of K562-S and K562-R cells by 60 to $65 \%$, without affecting the viability of the non-tumor cells, i.e. it exerted selective cytotoxicity towards Bcr-Abl ${ }^{+}$cell lines. In leukemic cell lines, the toxin induced apoptosis, activated caspases 3, 8, and 9, cleaved PARP, downregulated expression of the anti-apoptotic gene $B C L-2$, and upregulated expression of the pro-apoptotic gene BAD.

Conclusion: The antitumor effect of MJTX-I is associated with its potential to induce apoptosis and cytotoxicity in BcrAbl positive cell lines sensitive and resistant to imatinib mesylate, indicating that MjTX-I is a promising candidate drug to upgrade the CML therapy.
\end{abstract}

Keywords: Chronic myeloid leukemia, Bcr-Abl, Phospholipase A2, MjTX-I, Bothrops moojeni, Apoptosis, Cytotoxicity

\section{Background}

Chronic myeloid leukemia (CML) is a $B C R-A B L 1^{+}$myeloproliferative neoplasm [1], characterized by increased myeloproliferation rate and presence of apoptosis-resistant leukemic cells $[2,3]$. The current CML treatment relies on administration of the tyrosine kinase inhibitors imatinib mesylate (IM), dasatinib or nilotinib as first-line therapy.

\footnotetext{
*Correspondence: sandra_burin@yahoo.com.br

Departamento de Análises Clínicas, Toxicológicas e Bromatológicas.

Faculdade de Ciências Farmacêuticas de Ribeirão Preto, Universidade de São

Paulo, Ribeirão Preto, SP, Brazil
}

(c) The Author(s). 2018 Open Access This article is distributed under the terms of the Creative Commons Attribution 4.0 International License (http://creativecommons.org/licenses/by/4.0/), which permits unrestricted use, distribution, and reproduction in any medium, provided you give appropriate credit to the original author(s) and the source, provide a link to the Creative Commons license, and indicate if changes were made. The Creative Commons Public Domain Dedication waiver (http://creativecommons.org/publicdomain/zero/1.0/) applies to the data made available in this article, unless otherwise stated.

IM has been efficient to manage CML, but some patients have developed resistance to this therapy; when the therapeutic intervention fails, CML patients progress to the blast phase, which is almost always fatal [2, 4-6]. The main causes of resistance are related to either mutations at the Bcr-Abl catalytic site, such as the T315I, or to $B C R-A B L 1$ duplication or overexpression [7,8]. Despite all the advances and successes in CML therapy, it remains a challenge to find an efficient treatment to CML patients who are resistant to tyrosine kinase inhibitors. 
The antitumor effect of snake venoms has been explored since the last century [9-11]. Snake venoms hold many bioactive proteins, among which the phospholipase $\mathrm{A}_{2}\left(\mathrm{PLA}_{2}\right)$ isoforms, also called myotoxins, are one of the most abundant components $[12,13]$. PLA 2 not only exerts toxic and digestive effects, but also exhibits pharmacological and cytotoxic activity [14-16]. Studies have reported the cytotoxic and pro-apoptotic effects of a variety of $\mathrm{PLA}_{2}$ isolated from snake venoms in different tumor cell lines such as HL-60 (human promyelocytic leukemia), HepG2 (human hepatoma), PC12 (adrenal phaeochromocytoma), B16F10 (melanoma), Jurkat (acute T cell leukemia), SKBR-3 (human breast cancer), and Ehrlich ascites tumor [17-22].

The $\mathrm{PLA}_{2}$ isoforms are divided into two categories: neurotoxic (family Elapidae - genus micrurus) and non-neurotoxic (family Viperidae - genera Crotalus and Bothrops) [23]. The isoforms isolated from snakes belonging to the genus Bothrops are the main venom components that account for cell damage mediated by hydrolysis of membrane phospholipids [24]. The MjTX-I isolated from Bothrops moojeni snake venom (B. moojeni myotoxin I) is genotoxic to human lymphocyte DNA. BthTX-I and BthTX-II isolated from Bothrops jararacussu snake venom also damage lymphocyte DNA [25]. The mechanisms by which toxins isolated from snake venoms cause genotoxicity have not been elucidated yet, but they are probably related to the toxin-mediated free radical production [25-27].

Considering the need to search for new molecules to treat CML, and the knowledge that MjTX-I is cytotoxic, here we examined whether this myotoxin exerts antitumor effect against the $\mathrm{Bcr}-\mathrm{Abl}^{+}$cell lines sensitive (K562-S) or resistant (K562-R) to imatinib mesylate, a drug used as first-line treatment for CML.

\section{Material and methods \\ Cell lines}

This study used the cell lines K562-S (IM-sensitive $\mathrm{Bcr}^{-\mathrm{Abl}^{+}}$cells) and $\mathrm{K} 562-\mathrm{R}$ (IM-resistant $\mathrm{Bcr}-\mathrm{Abl}^{+}$ cells), isolated from CML patients in blast phase who were sensitive or resistant to IM treatment, respectively. The cell lines were kindly provided by Dr. JPGAM. HEK-293 cells, derived from embryonic epithelial cells of human kidney, were acquired from the Rio de Janeiro Cell Bank (BCRJ: 0009) and kindly provided by Professor AML.

K562-S and K562-R cells were cultured in complete RPMI (Roswell Park Memorial Institute) 1640 medium, while HEK-293 cells were cultured in complete DMEM (Dulbecco's Modified Eagle Medium). Both culture media were supplemented with $10 \%$ fetal bovine serum and $1 \%$ penicillin/streptomycin, and the three cell lines were incubated under an atmosphere of $5 \% \mathrm{CO}_{2}$ and $95 \%$ air, at $37^{\circ} \mathrm{C}$.

\section{Isolation and purification of MjTX-I}

Bothrops moojeni snake venom was donated by the Center for the Study of Venoms and Venomous Animals (CEVAP) from São Paulo State University (UNESP), Botucatu, São Paulo, Brazil, and stored at $-20^{\circ} \mathrm{C}$. The MjTX-I (B. moojeni myotoxin I) was purified from Botrops moojeni crude venom through anion-exchange chromatography on CM-Sepharose (Pharmacia) adapted from Lomonte et al. [28]. The eluted toxin homogeneity was analyzed by SDS-PAGE and reversed-phase chromatography.

\section{Isolation of peripheral blood mononuclear cells (PBMC)}

Peripheral blood was collected into vacuum tubes containing anticoagulant, from three healthy individuals aged between 30 and 40 years after their consent. The human peripheral blood mononuclear cells (PBMC) were isolated by the Ficoll-Hypaque density gradient centrifugation method, using Histopaque-1077 (Sigma Diagnostics, Inc., MO, USA). After centrifugation (500 x g for $30 \mathrm{~min}$ ), the PBMC-rich layer was collected and suspended in $1 \mathrm{~mL}$ of complete RPMI. Cells were diluted in Turk's dye and counted in the Neubauer's chamber. Next, the cells were plated, treated with MjTX-I, and incubated under an atmosphere of $5 \% \mathrm{CO}_{2}$, at $37^{\circ} \mathrm{C}$.

\section{Cytotoxicity assay}

Cell viability was assessed using the 3-(4,5-dimethylthiazol-2-yl)-2,5-diphenyltetrazolium bromide (MTT) method described by Mosmann [29], with modifications. The tumor cell lines K562-S and K562-R and the non-tumor cells HEK-293 and PBMC $\left(2 \times 10^{4}\right.$ cells $)$ were treated for $24 \mathrm{~h}$ with MjTX-I at different concentrations $(3.15,6.25,12.5,25,50,75,100,150,200,300$, and $400 \mu \mathrm{g} / \mathrm{mL}$ ). Untreated cells were used as negative control, and cells treated with $1 \%$ Triton X-100 (Bio-Rad, Hercules, CA, USA) were used as positive control. Next, $20 \mu \mathrm{L}$ of MTT $(5 \mathrm{mg} / \mathrm{mL})$ were added to each well, and the microplate was incubated for $4 \mathrm{~h}$, at $37^{\circ} \mathrm{C}$. The supernatants were discarded, and the formazan crystals were dissolved with $200 \mu \mathrm{L}$ of dimethyl sulfoxide. After $30 \mathrm{~min}$ of incubation at room temperature, the absorbance was recorded at $570 \mathrm{~nm}$. The percentage of cell viability was used to calculate the toxin concentration capable of killing $50 \%$ of the cells $\left(\mathrm{IC}_{50}\right)$. The IC50 was calculated by using the Calcusyn 2.1 software.

\section{Apoptosis analyses}

\section{Flow cytometric quantification of apoptosis}

The toxin potential to sensitize cells to and induce apoptosis was quantified using the hypotonic fluorescent solution (HFS) method reported by Riccardi and Nicoletti [30]. K562-S and K562-R cells $\left(1 \times 10^{5}\right.$ cells $)$ were treated for $24 \mathrm{~h}$ with MjTX-I at 6.25, 12.5, 50, and 
$100 \mu \mathrm{g} / \mathrm{mL}$, as well as at the concentrations corresponding to the $\mathrm{IC}_{50}$ values for these cell lines: 257 and $191 \mu \mathrm{g} / \mathrm{mL}$, respectively. Untreated cells were used as the negative control, and $25 \mu \mathrm{M}$ Etoposide (VP-16) was used as the cell death control. Next, the cells were recovered, transferred to flow cytometry tubes, and suspended in $400 \mu \mathrm{L}$ of HFS solution $(50 \mu \mathrm{g} / \mathrm{mL}$ propidium iodide, $0.1 \%$ sodium citrate, and $0.1 \%$ Triton $\mathrm{X}-100$ ). After a 15 -min incubation in the dark, at $4{ }^{\circ} \mathrm{C}$, cells were analyzed in the FACSCanto flow cytometer (BD, Sunnyvale, CA, USA), with the aid of the FACSDiva software (BD, San Diego, CA, USA). Five thousand events were acquired and the cell population was analyzed to determine the percentage of hypodiploid nuclei (apoptotic nuclei).

\section{Western blotting detection of caspase activation and poly} (ADP-ribose) polymerase (PARP) cleavage

K562-S and K562-R cells $\left(1 \times 10^{6}\right.$ cells $)$ were treated for $24 \mathrm{~h}$ with MjTX-I $(6.25,12.5,50,100,257$, and $191 \mu \mathrm{g} /$ $\mathrm{mL}$ ), VP-16 $25 \mu \mathrm{M}$ (positive control), or culture media (negative control). Afterward, the cells were collected and suspended in the western blotting lysis buffer (20 $\mathrm{mM}$ Tris- $\mathrm{HCl} \mathrm{pH}$ 7.4, $150 \mathrm{mM} \mathrm{NaCl}, 1 \mathrm{mM}$ EDTA, and phosphatase and protease inhibitors). Total protein concentration in the samples was determined using the $\mathrm{BCA}$ protein assay reagent, according to the manufacturer's instructions (Thermo Fischer Scientific, Waltham, MA, USA). Equal amounts of protein were analyzed by 15\% SDS-PAGE (sodium dodecyl sulfate polyacrylamide gel electrophoresis), where they were separated according to their molecular weight. Next, proteins were transferred to polyvinylidene difluoride (PVDF) membranes (Amersham, GE Healthcare Life Science, Pittsburgh, PA, USA). To detect the proteins, the membranes were first blocked for $2 \mathrm{~h}$ with $5 \%$ non-fat dry milk prepared in Tris-buffered saline with Tween-20 (20 mM Tris, 137 $\mathrm{mM} \mathrm{NaCl}, 0.01 \%$ Tween-20). The PVDF membranes were incubated overnight, at $4{ }^{\circ} \mathrm{C}$, with the following primary antibodies acquired from Cell Signaling Technology (Danvers, MA, USA): anti-caspase 3 (code 96625), anti-caspase 8 (code 9746), anti-caspase 9 (code 9502), anti-PARP (code 9541), and anti- $\beta$-tubulin (code 2146). Then, the PVDF membranes were incubated with the appropriate secondary antibodies and the expression of target proteins were detected using ECL (Amersham, GE Healthcare Life Science, Pittsburgh, PA, USA). The protein tubulin was used as an internal standard to normalize protein load among samples.

\section{Expression of apoptosis-related genes}

Total RNA extraction

Total RNA from K562-S and K562-R cells $\left(1 \times 10^{6}\right.$ cells $)$ treated with MjTX-I at low concentrations (6.25 and
$12.5 \mu \mathrm{g} / \mathrm{mL}$ ) was extracted using the Trizol $^{\circ}$ method, following the manufacturer's instructions (Invitrogen Life Technologies ${ }^{\circ}$, Carlsbad, USA). Untreated cells were used as the negative control. RNA concentration of all samples was determined by the absorbance ratio determined at $260 \mathrm{~nm}$ and $280 \mathrm{~nm}$ (A260/A280), using the NanoVue spectrophotometer (GE Healthcare Life Sciences, Pittsburgh, PA, USA).

\section{Complementary DNA (CDNA) synthesis and real-time polymerase chain reaction (PCR)}

Total RNA $(1 \mu \mathrm{g})$ was reverse transcribed to cDNA synthesis using the High Capacity cDNA reverse transcription $^{\circ}$ assay kit (Applied Biosystems ${ }^{\bullet}$, Foster City, USA), according to the manufacturer's instructions. cDNA (diluted 1:4) was used in the real time PCR assay to analyze expression of apoptosis-related genes: $B A D, B A X$ (pro-apoptotic members from $\mathrm{Bcl}-2$ family), $B C L-2, B C L-X_{L}$ (anti-apoptotic members from Bcl-2 family), and the c-FLIP (anti-apoptotic gene from apoptosis extrinsic pathway). Gene expression was quantified by real time PCR (three experiments assayed in duplicate) using the SYBR Green PCR Master Mix Kit (Applied Biosystems, Carlsbad, CA, USA) and the StepOnePlus ${ }^{\mathrm{Tt}}$ equipment (Applied Biosystems). The results were normalized by the geometric mean of the $\beta$-actin and the B2M housekeeping genes expression and represented by $2-\Delta \Delta \mathrm{Ct}$. The sequences of the specific oligonucleotides (Invitrogen Life Technologies) used for quantification of gene expression are listed in Table 1.

\section{Statistical data analysis}

Experimental data were compared using One-way Analysis of Variance (ANOVA) followed by the Tukey's post-hoc test, with the aid of the GraphPad Prism software, version 5.0 (GraphPad Software, San Diego,

Table 1 Oligonucleotide sequences used for quantification of gene expression

\begin{tabular}{|c|c|}
\hline Target Gene & Oligonucleotide Sequence (5' to $3^{\prime}$ ) \\
\hline$\overline{B A D}$ & $\begin{array}{l}\text { F: CCG AGT GAG CAG GAA GAC TC } \\
\text { R: GGT AGG AGC TGT GGC GAC T }\end{array}$ \\
\hline$B A X$ & $\begin{array}{l}\text { F: CCC TTT TGC TTC AGG GTT TC } \\
\text { R: TCT TCT TCC AGA TGG TGA GTG }\end{array}$ \\
\hline$B C L-2$ & $\begin{array}{l}\text { F: ACG AGT GGG ATG CGG GAG ATG TG } \\
\text { R: GCG GTA GCG GCG GGA GAA GTC }\end{array}$ \\
\hline$B C L-X_{L}$ & $\begin{array}{l}\text { F: CTG AAT CGG AGA TGG AGA CC } \\
\text { R: TGG GAT GTC AGG TCA CTG AA }\end{array}$ \\
\hline$c-F L I P$ & $\begin{array}{l}\text { F: GCC GAG GCA AGA TAA GCA } \\
\text { R: GCC CAG GGA AGT GAA GGT }\end{array}$ \\
\hline$\beta-A C T I N$ & $\begin{array}{l}\text { F: GCC CTG AGG CAC TCT TCC A } \\
\text { R: CCA GGG CAG TGA TCT CCT TCT }\end{array}$ \\
\hline$B 2 M$ & $\begin{array}{l}\text { F: CCA GCG TAC TCCC AAA GAT TCA } \\
\text { R: TGG ATG AAA CCC AGA CAC ATA G }\end{array}$ \\
\hline
\end{tabular}

$F$ Forward Primer, $R$ Reverse Primer 
California, USA). $p<0.05$ were considered as statistically significant.

\section{Results}

MjTX-I is cytotoxic towards leukemic cells but not towards non-tumor cells

We examined the cytotoxicity of MjTX-I towards the tumor cell lines K562-S and K562-R, and towards the non-tumor cells HEK-293 and PBMC, after a 24-h treatment with toxin concentrations ranging from 3.15 to $400 \mu \mathrm{g} / \mathrm{mL}$. The percentage of cell viability of K562-S and K562-R cells treated with the toxin at concentrations higher than $100 \mu \mathrm{g} / \mathrm{mL}$ and $75 \mu \mathrm{g} / \mathrm{mL}$, respectively, decreased significantly $(p<0.05)$, and reached 40 and $35 \%$ after treatment with $400 \mu \mathrm{g} / \mathrm{mL}$ of the toxin, respectively. The $\mathrm{IC}_{50}$ values for $\mathrm{K} 562-\mathrm{S}$ and $\mathrm{K} 562-\mathrm{R}$ cells were $257 \mu \mathrm{g} / \mathrm{mL}$ and $191 \mu \mathrm{g} / \mathrm{mL}$, respectively (Fig. 1a and b). In non-tumor cells, MjTX-I reduced cell viability of HEK-293 cells by $25 \%$ at the highest concentration tested $(400 \mu \mathrm{g} / \mathrm{mL})$, and reduced cell viability of PBMC by $34-38 \%$ at the two highest concentrations tested (300 and $400 \mu \mathrm{g} / \mathrm{mL}$ ) (Fig. 2a and b).

\section{MjTX-I induces cell death in leukemic cell lines}

After analyzing the cytotoxicity of MjTX-I, we examined whether it sensitized Bcr-Abl ${ }^{+}$cell lines to apoptosis. Cell death was assessed by quantifying formation of hypodiploid nuclei (apoptotic nuclei). Compared with the control, the percentage of hypodiploid nuclei increased by $45.5-62 \%$ in K562-S cells treated with $50-257 \mu \mathrm{g} / \mathrm{mL}$ of the toxin $(p<0.05$; Fig. 3a), and by 34 and $54 \%$ in K562-R cells treated with 100 and $191 \mu \mathrm{g} / \mathrm{mL}$ of the toxin, respectively ( $\mathrm{p}<0.05$; Fig. $3 \mathrm{~b}$ ). MjTX-I at low concentrations promoted a weak but not significant increase in the percentage of hypodiploid nuclei (10-20\%) (Fig. 3a and $b$ ).
MjTX-I induces caspases activation in leukemic cell lines We examined the activation of caspases 3, 8, and 9 and PARP cleavage in K562-S and K562-R cells to confirm apoptosis induction, as wells as to determine which apoptosis pathway was activated - intrinsic or extrinsic - in these cells. MjTX-I at 100 and $257 \mu \mathrm{g} / \mathrm{mL}$ induced high levels of cell death, which thereby impaired preparation of cell lysate and protein quantification.

In K562-S cells, MjTX-I at $50 \mu \mathrm{g} / \mathrm{mL}$ lowered the levels of pro-caspase 3 expression, while the toxin at 6.25 and $12.5 \mu \mathrm{g} / \mathrm{mL}$ increased the levels of caspase-9 expression and PARP cleavage (Fig. 4a). In K562-R cells, the toxin lowered the levels of pro-caspase 3 and pro-caspase 9 expression at 100 and $191 \mu \mathrm{g} / \mathrm{mL}$, lowered the levels of pro-caspase 8 expression at 6.25 and $12.5 \mu \mathrm{g} / \mathrm{mL}$, and increased the levels of cleaved PARP at concentrations greater than $12.5 \mu \mathrm{g} / \mathrm{mL}$ (Fig. $4 \mathrm{~b}$ ). Treatment with VP-16 lowered the levels of pro-caspase 3 and increased the levels of cleaved PARP in K562-S and K562-R cells (Fig. 4a and b); in the former cell line, it also augmented the levels of caspase 9 expression (Fig. 4a).

The disappearance of specific bands of caspases proforms and the appearance of bands of the cleaved forms indicated caspases activation. These findings suggest that MjTX-I induced apoptosis by activating the intrinsic and extrinsic pathways.

\section{MjTX-I modulates expression of apoptosis-related genes}

After confirming that MjTX-I was capable of inducing cell death in leukemic cells, we selected sub lethal concentrations that sensitized cells to apoptosis -6.25 and $12.5 \mu \mathrm{g} / \mathrm{mL}$ - and examined whether they modulated the expression of pro- and anti-apoptotic genes in K562-S and K562-R cells. In K562-S cells, MjTX-I lowered the expression level of the anti-apoptotic gene $B C L-2$ (fold change $=0.32$ ) at $6.25 \mu \mathrm{g} / \mathrm{mL}$, and lowered
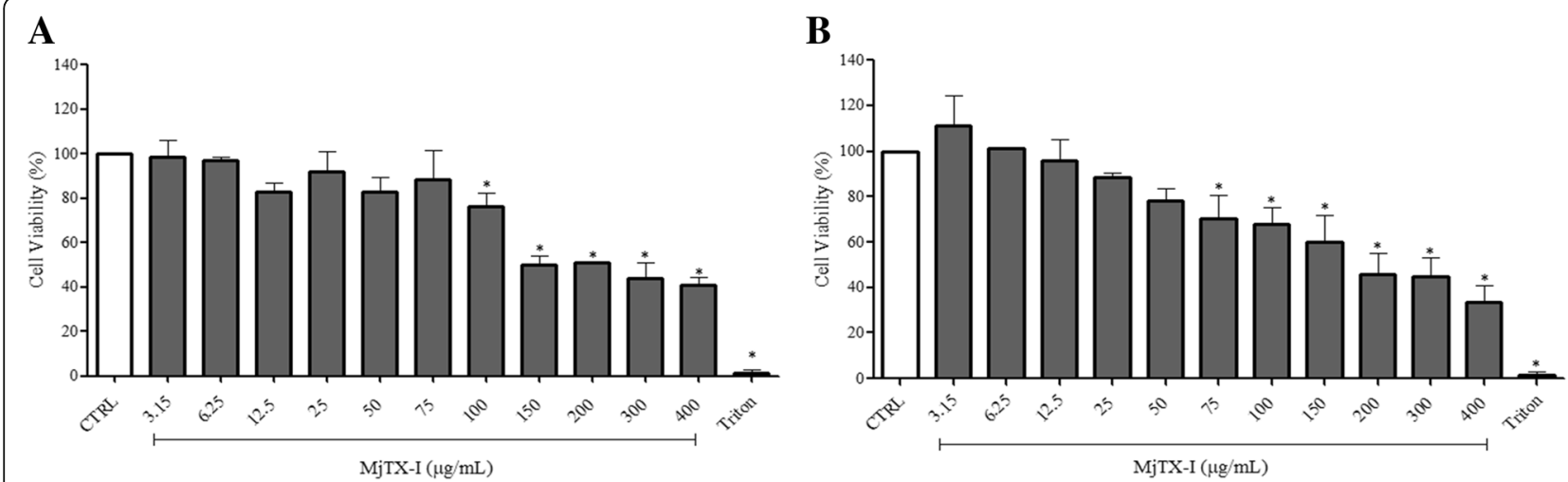

Fig. 1 Cytotoxicity of MjTX-I towards (a) K562-S (b) K562-R tumor cell lines. Results are expressed as the mean percentage of cell viability \pm standard deviation of three independent experiments assayed in triplicate. CTRL: untreated cells (negative control). ${ }^{*} p<0.05$ vs. CTRL (One-way ANOVA followed by the Tukey's post-hoc test) 

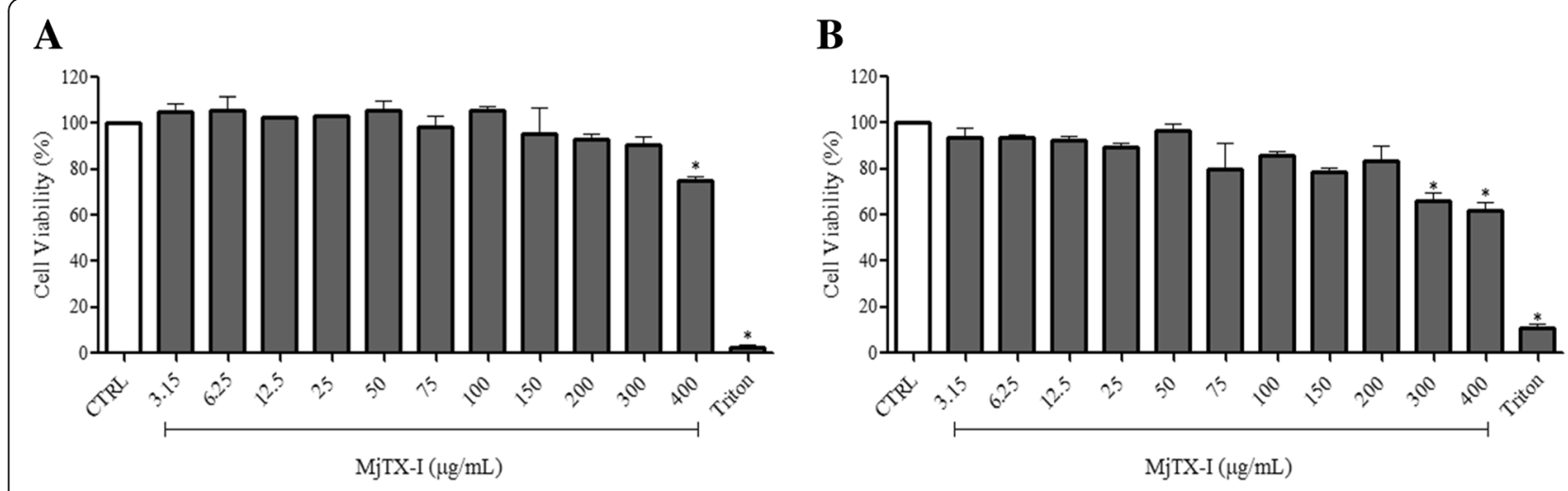

Fig. 2 Cytotoxicity of MjTX-I towards (a) HEK-293 and (b) PBMC non-tumor cells. Results are expressed as the mean percentage of cell viability \pm standard deviation of three independent experiments assayed in triplicate. CTRL: untreated cells (negative control). ${ }^{*} p<0.05$ vs. CTRL (One-way ANOVA followed by the Tukey's post-hoc test)

the expression levels of all the genes analyzed herein at $12.5 \mu \mathrm{g} / \mathrm{mL}: B A D$ (fold change $=0.11$ ), $B A X$ (fold change $=0.27), B C L-2$ (fold change $=0.31), B C L-X_{L}$ (fold change $=0.11$ ), and $c$-FLIP (fold change $=0.21$ ) (Fig. 5a). MjTX-I at $12.5 \mu \mathrm{g} / \mathrm{mL}$ also increased the expression level of the pro-apoptotic gene $B A D$ (fold change $=7.5$ ) in K562-R cells (Fig. 5b), which was $49 \%$ greater than that detected in K562-S cells (Fig. 5c).

\section{Discussion}

Toxins isolated from snake venom, such as $\mathrm{PLA}_{2}$, have been prominent as potent antitumor agents in the last years. Scientists have investigated this enzyme class as a promising tool to develop new candidate drugs to treat cancer [13, 18, 31]. The present study examined the cytotoxic and pro-apoptotic effect of the myotoxin MjTX-I isolated from Bothrops moojeni snake venom, with the purpose of better understanding its mechanism of action and describing a molecule that could help to treat CML.

We found that MjTX-I was cytotoxic towards the leukemic cell lines $\mathrm{K} 562-\mathrm{S}$ and $\mathrm{K} 562-\mathrm{R}$ and reduced their viability by 60 and $65 \%$, respectively. The literature reports the antitumor potential of $\mathrm{PLA}_{2}$ isolated from snake venom towards other tumor cell lines. For instance, BthTX-I at $10-100 \mu \mathrm{g} / \mathrm{mL}$ reduces cell viability of the tumor cell lines HL-60, PC12, and B16F10 by 40$60 \%$ [18]; two $\mathrm{PLA}_{2}$ isolated from Bothrops brazili, named as MTX-I and MTX-II, at $100 \mu \mathrm{g} / \mathrm{mL}$ are cytotoxic towards Jurkat cells [20]; BthA-IPLA ${ }_{2}$, the acidic $\mathrm{PLA}_{2}$ isolated from Bothrops jararacussu, at $100 \mu \mathrm{g} / \mathrm{mL}$ is cytotoxic towards Jurkat, SKBR-3, and Ehrlich ascites tumor cells [22].

The cytotoxic mechanisms of $\mathrm{PLA}_{2}$ are poorly understood. This enzyme class directly acts on the membrane phospholipid metabolism and interferes with lipid
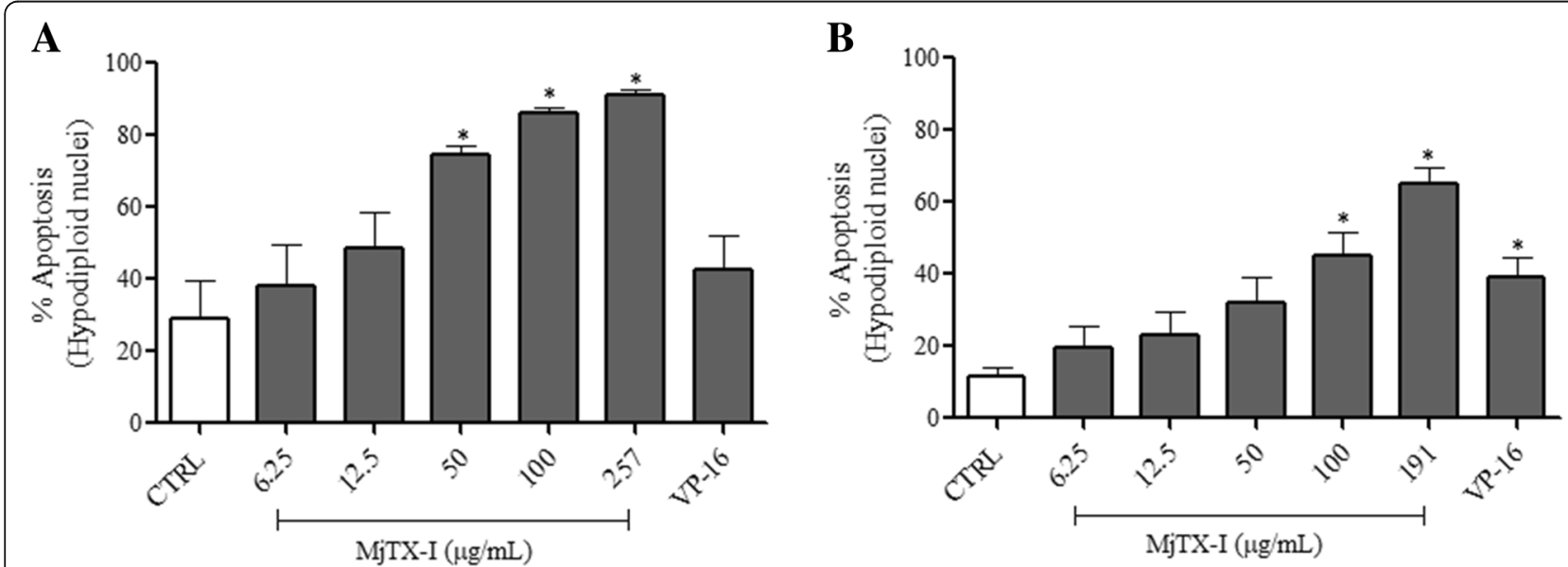

Fig. 3 Quantification of MjTX-l-induced apoptosis in (a) K562-S and (b) K562-R cells, assessed by the hypotonic fluorescent solution (HFS) method. Results are expressed as mean percentage of cells with hypodiploid nuclei \pm standard deviation of three independent experiments. CTRL: untreated cells (negative control). VP-16: etoposide (positive control). * $p<0.05$ vs. CTRL (One-way ANOVA followed by the Tukey's post-hoc test) 


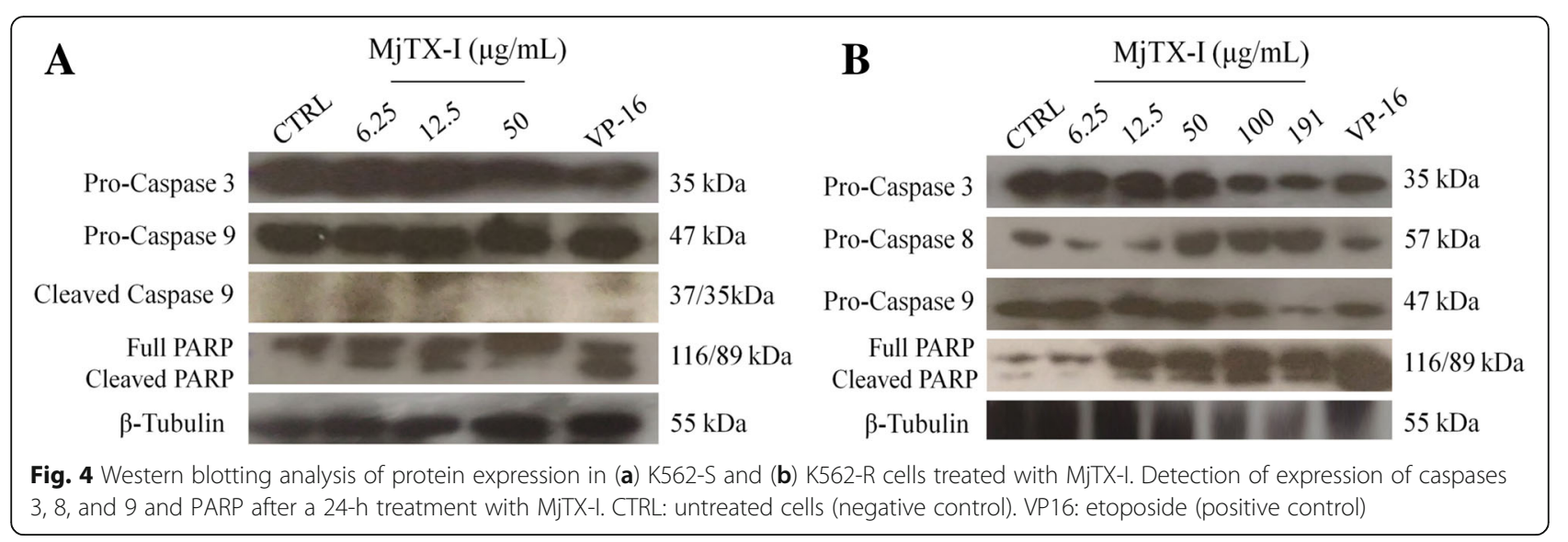

biosynthesis in a variety of cell lines, including tumor cell lines [31]. The myotoxin C-terminal region can disrupt the membrane hydrophilic matrix and cause the opening pores and the toxin entry into the intracellular environment [32]. In other words, one hypothesis is that the interaction between the toxin $\mathrm{C}$-terminal region and cell membranes mediate the cytotoxicity of myotoxins $[20,21,33]$. Another possibility is that PLA $\mathrm{P}_{2}$ triggers the production of reactive oxygen species and induces oxidative stress, which are associated with the cytotoxic effects [25-27].

Considering that toxins isolated from snake venoms are potential candidates for the development of new drugs, and that their administration may pose risk to human health, their cytotoxic effects should also be assessed in non-tumor cells. Here we demonstrated that the non-tumor cells HEK-293 and PBMC were resistant to the cytotoxic effect of MjTX-I, since toxin concentrations as high as 300 and $400 \mu \mathrm{g} / \mathrm{mL}$ decreased cell viability by no more than $38 \%$.

There are few reports on the action of $\mathrm{PLA}_{2}$ on non-tumor cells. In line with our findings, there are evidences that $\mathrm{PLA}_{2}$ is more strongly cytotoxic towards tumor cells than towards non-tumor cells. The non-tumor cell lines HEK-293 and C2C12 (mouse skeletal muscle cell) were resistant to the cytotoxic effects of AtxA, a PLA $\mathrm{P}_{2}$ isolated from Vipera ammodytes ammodytes that is strongly cytotoxic towards the tumor cell line NSC34 (Neuroblastoma) [34]. Some studies on the cytotoxicity, genotoxicity, and mutagenicity of some $\mathrm{PLA}_{2}$ in human lymphocytes have revealed that $\mathrm{CB}$ $\mathrm{PLA}_{2}$ and CA-crotapotin - two $\mathrm{PLA}_{2}$ isolated from Crotalus durissus terrificus - are not cytotoxic and cause reversible DNA damage [27]; the PLA ${ }_{2}$ BthTX-I, BthTX-II, and MjTX-I are not cytotoxic; and MjTX-I causes weaker DNA damage than the other PLA 2 . In this sense, the findings of the present study may have relevant clinical implications because one of the requirements of cancer therapy is the selective toxicity to tumor cells, i.e. low toxicity to non-tumor cells.

Next, we examined the pro-apoptotic effect of MjTX-I to address whether it was capable of sensitizing cells to and/or inducing apoptosis. Quantification of apoptosis through the HFS method revealed that MjTX-I increased the formation of hypodiploid nuclei (apoptotic) in K562-S and K562-R cells, being the former more sensitive to the effect of the toxin. VP-16 also induced the formation of hypodiploid nuclei in both cell lines, but less strongly than the MjTX-I concentration that exerted significant effects; these findings confirm the resistance of both tumor cell lines to conventional chemotherapeutic agents.

As apoptosis is a dynamic process where the cellular events occur within a short time-window, different methods should be used to confirm this process. For this reason, here we analyzed the expression of the apoptotic proteins caspases 3,8 , and 9 and PARP by western blotting as well as the expression of pro- and anti-apoptotic genes by real-time PCR. Activation of caspases 3 and 9 followed by PARP cleavage in K562-R and K562-S cells indicates triggering of the intrinsic apoptosis pathway; in addition, activation of caspase 8 in K562-R cells suggests triggering of the extrinsic apoptosis pathway.

In line with the findings reported in the previous paragraph, we found that MjTX-I modulated the expression of pro- and anti-apoptotic genes. MjTX-I at both concentrations tested modulated gene expression in K562-S cells. This cell line was more sensitive to the toxin effect at $12.5 \mu \mathrm{g} / \mathrm{mL}$, which downregulated the expression of not only the anti-apoptotic genes $B C L-2, B C L-X L$, and $c$-FLIP, but also of the pro-apoptotic genes $B A D$ and $B A X$. The toxin at $6.25 \mu \mathrm{g} / \mathrm{mL}$ did not interfere in the expression of the pro-apoptotic genes but downregulated $B C L-2$ expression. MjTX-I did not modulate expression of the anti-apoptotic genes but increased $B A D$ expression by 7.5 -fold in K562-R cells. 


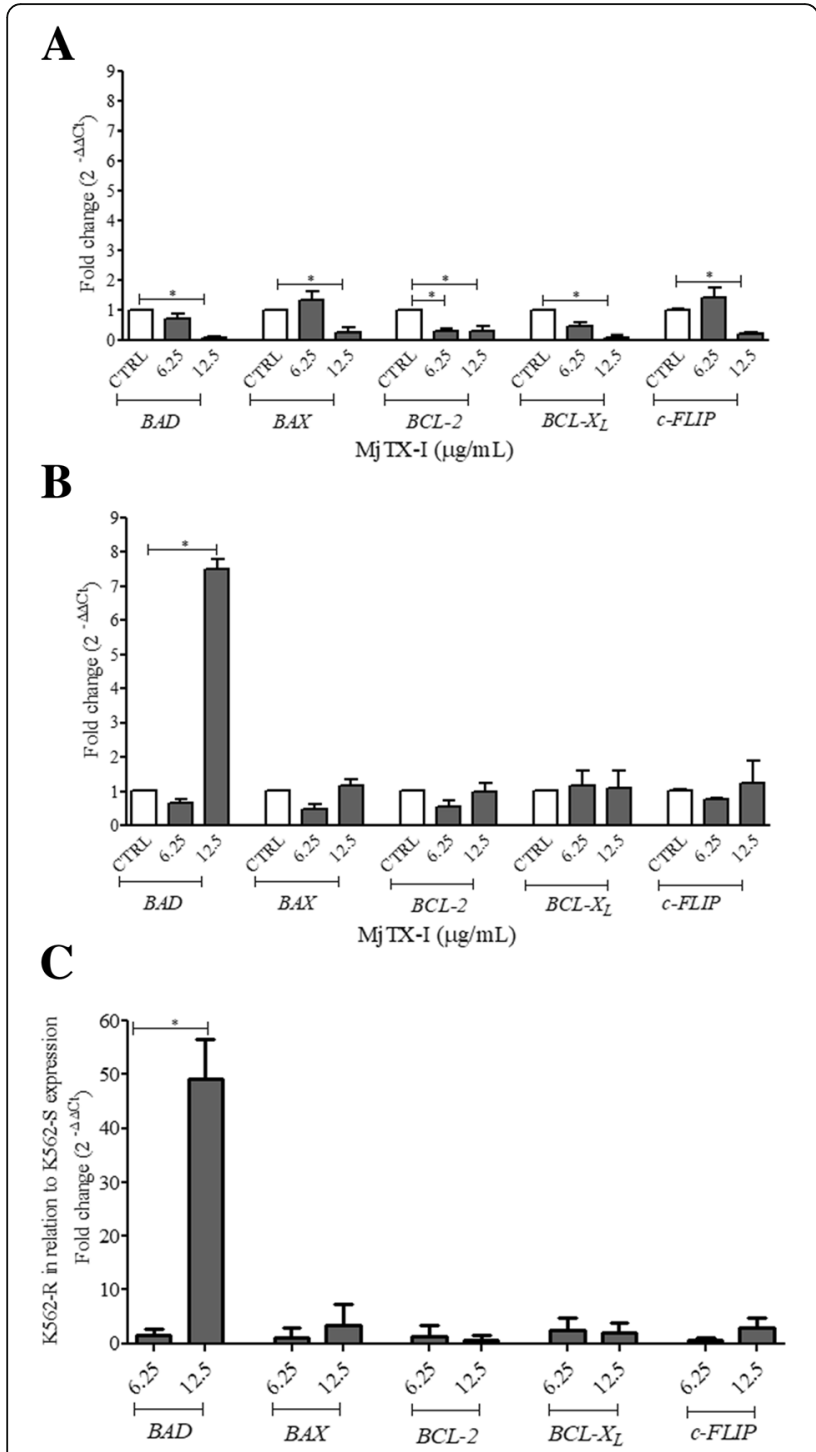

Fig. 5 Expression of apoptosis-related genes in K562-S and K562-R cells treated with MJTX-I. Expression of BAD, BAX, BCL-2, BCL-X, and CFLIP genes was analyzed by real-time PCR after a 24-h treatment with MjTX-I. (a) K562-S cells. (b) K562-R cells. (c) Gene expression ratio between K562-R and K562-S cells (fold change). Results are expressed as mean \pm standard deviation of three independent experiments. CTRL: untreated cells (control). ${ }^{*} p<0.05$ vs. CTRL (One-way ANOVA followed by the Tukey's post-hoc test)

K562-S and K562-R are the particular K562 cell sublines that are less or more resistant to chemotherapy drugs in vitro, respectively $[35,36]$. In K562-S and K562-R cells that are sensitive and resistant to imatinib mesylate, respectively, the present study demonstrated that treatment with similar MjTX-I concentrations differently modulated gene expression, and evidenced that the toxin increased expression of a pro-apoptotic gene in resistant cells more effectively than in sensitive cells. The K562-S and K562-R cells response to MjTX-I treatment differed probably due to karyotype variability [37] and the role that some membrane proteins play in K562-R cell resistance [35].

Tyrosine kinase activity of Bcr-Abl in CML is associated with apoptosis inhibition by increasing the expression of the anti-apoptotic proteins $\mathrm{Bcl}-2$ and $\mathrm{Bcl}-\mathrm{X}_{\mathrm{L}}[38,39]$, which play critical roles in the mitochondrial apoptosis pathway [40]. It is worth to note that Bcr-Abl positive cell lines are more resistant to cell death induced by different apoptosis inducers [41].

The anti-apoptotic protein Bcl-2 acts by suppressing the pro-apoptotic protein complex Bax/Bak; however, Bcl-2 inhibition activates this complex and induces apoptosis $[42,43]$. The pro-apoptotic protein Bad acts on the cytosol, more specifically it directly acts on the mitochondria and helps to inhibit $\mathrm{Bcl}-2$ and $\mathrm{Bcl}-\mathrm{X}_{\mathrm{L}}$; it thereby activates the intrinsic apoptosis pathway $[44,45]$. In this sense, the fact that MjTX-I activated caspase 3 through the intrinsic and extrinsic apoptosis pathways, downregulated $B C L-2$ expression, and upregulated $B A D$ expression indicate that this toxin is a promising molecule for the adjuvant treatment of CML.

Other studies have demonstrated the pro-apoptotic effect of $\mathrm{PLA}_{2}$. BthTX-I at 25, 50, and $100 \mu \mathrm{g} / \mathrm{mL}$ elicits apoptosis in the tumor cell lines PC-12, B16F10, HL-60, and HepG2 [18]. The phospholipase MT-II (homologue of $\mathrm{PLA}_{2}$ from Bothrops asper) induces apoptosis and cell proliferation, depending on the toxin concentration tested, as assessed by the TUNEL method [46]. AtxA at $100 \mathrm{nmol} / \mathrm{L}$ exerts cytotoxicity associated with apoptosis induction in the tumor cell line NSC34 [34].

The loss of mitochondrial membrane potential and caspase 3 activation confirmed our findings. Corroborating our data, CMS-9 (a PLA 2 isolated from Naja nigricollis venom) at $0.1 \mu \mathrm{M}$ induces apoptosis in K562 cells. Mitochondrial depolarization and activation of caspases 3 and 9 confirmed the pro-apoptotic action of this toxin. CMS-9 also modulates expression of pro- and anti-apoptotic proteins: it lowers Bcl-2 expression and increases expression and mitochondrial translocation of Bax [47].

The mechanisms by which $\mathrm{PLA}_{2}$ induces apoptosis and exerts cytotoxicity in tumor cell lines are not completely understood. Some authors propose that $\mathrm{PLA}_{2}$-induced apoptosis is related to the cytotoxic effects of these enzymes [48], while others believe that $\mathrm{PLA}_{2}$ accelerates phospholipid turnover and influences on the membrane alterations that occur during the apoptotic process $[20,49]$. Another hypothesis is that the pro-apoptotic action of $\mathrm{PLA}_{2}$ is associated with oxidative stress caused by the release of reactive oxygen species and increase of intracellular $\mathrm{Ca}^{2+}$ concentration in the mitochondrial matrix region due to formation of membrane permeability transition pores $[25,47,50]$.

Together, the results reported herein stress the apoptosis-inducing capacity of $\mathrm{PLA}_{2}$ and contribute to 
better understand the mechanisms by which this toxin class act. Therefore, MjTX-I can be considered as an enzyme with promising therapeutic applications.

\section{Conclusion}

MjTX-I exerts selective cytotoxicity against leukemic cell lines, with low toxicity towards non-tumor cells, and induces apoptosis accompanied by caspases activation and downregulation of $B C L-2$ and upregulation of $B A D$ expression. Our findings add important knowledge to the mechanisms underlying the action of snake venom phospholipases, as well as help to improve the CML therapy.

\begin{abstract}
Abbreviations
AtXA: Phospholipase isolated from Vipera ammodytes ammodytes; BthTX-I and BthTX-II: Phospholipases isolated from Bothrops jararacussu; CDNA: Complementary DNA; CML: Chronic myeloid leukemia; CMS9: Phospholipase isolated from Naja nigricollis; HFS: Hypotonic fluorescent solution; $\mathrm{IC}_{50}$ : Toxin concentration that kills $50 \%$ of the cell lines; IM: Imatinib mesylate; MjTX-I: Myotoxin PLA - Lys49 isolated from Bothrops moojeni; MTT: (3-(4,5-dimethylthiazol-2-yl)-2,5-diphenyltetrazolium bromide; PARP: Poly-(ADP-ribose)-polymerase; PBMC: Peripheral blood mononuclear cells; PCR: Polymerase chain reaction; PLA 2 : Phospholipase $A_{2}$; PVDF: Polyvinylidene difluoride; VP-16: Etoposide
\end{abstract}

\section{Acknowledgements}

The authors are grateful to Fabiana Rossetto de Morais for the technical support during the flow cytometry analyses and Thiago A. Silva and Sante Emmanuel Imai Carone for the technical support during MjTX-I isolation and prurification.

\section{Funding}

This research work was financially supported by the Animal Toxins Research Support Center (NAP-TOXAN- USP, grant \# 12.1.17615.1.5), the São Paulo Research Foundation (FAPESP, grants \# 2011/23236-4, 2015/25637-7, 2014/ 04234-9, and 2015/00740-0), and partially supported by the Coordination for the Improvement of Higher Education Personnel (CAPES) - through "Programa Editoração CAPES", call \#13/2016, grant \#0722/2017, record \# 88881.142062/2017-01 -, and the National Council for Scientific and Technological Development (CNPq) - through "Programa Editorial CNPq/ CAPES", call \#26/2017, grant \# 440954/2017-7.

\section{Availability of data and materials}

All data generated or analyzed during this study are included in this published article [and its supplementary information files].

\section{Authors' contributions}

RBB performed the experiments, analyzed the data and wrote the manuscript. TRC performed the MTT experiments and discussed the results. MCC performed the western blotting assays, discussed the results and reviewwd the manuscript. FAC and SVS designed the study, discussed the results, reviewed the manuscript and provided the funding for project development. SMB designed the study, performed the experiments, analyzed the data, discussed the results and wrote the manuscript. All authors carefully read the paper and approved the final version.

\section{Ethics approval and consent to participate}

We declare that The Human Research Ethics Committee of the School of Pharmaceutical Sciences of Ribeirão Preto, University of São Paulo, Brazil, approved this study protocol, which was registered under the code CEP/ FCFRP 032/2018. We declare that the study was conducted with the consent of the human participants.

\section{Consent for publication}

Not applicable.

\section{Competing interests}

The authors declare that they have no competing interests.

\section{Publisher's Note}

Springer Nature remains neutral with regard to jurisdictional claims in published maps and institutional affiliations.

Received: 11 July 2018 Accepted: 6 December 2018

Published online: 20 December 2018

\section{References}

1. Arber DA, Orazi A, Hasserjian R, Thiele J, Borowitz MJ, Le Beau MM, et al. The 2016 revision to the World Health Organization classification of myeloid neoplasms and acute leukemia. Blood. 2016;127(20):2391-405.

2. Chereda B, Melo JV. Natural course and biology of CML. Ann Hematol. 2015; 94(Suppl 2):S107-21.

3. Melo JV, Hughes TP, Apperley JF. Chronic myeloid leukemia. Hematol Am Soc Hematol Educ Program. 2003:132-52.

4. Weisberg E, Manley PW, Cowan-Jacob SW, Hochhaus A, Griffin JD. Second generation inhibitors of $B C R-A B L$ for the treatment of imatinib-resistant chronic myeloid leukaemia. Nat Rev Cancer. 2007;7(5):345-56.

5. Balabanov S, Braig M, Brümmendorf TH. Current aspects in resistance against tyrosine kinase inhibitors in chronic myelogenous leukemia. Drug Discov Today Technol. 2014;11:89-99.

6. DDA R, VDDS F, Berzoti-Coelho MG, Burin SM, Magro CL, MDC C, et al. MLL2/KMT2D and MLL3/KMT2C expression correlates with disease progression and response to imatinib mesylate in chronic myeloid leukemia. Cancer Cell Int. 2018;18(1) [cited 2018 Jun 29].

7. Breccia M, Alimena G. Second-generation tyrosine kinase inhibitors (Tki) as salvage therapy for resistant or intolerant patients to prior TKIs. Mediterr J Hematol Infect Dis. 2014;6(1):e2014003.

8. Baccarani M, Castagnetti F, Gugliotta G, Rosti G. A review of the European LeukemiaNet recommendations for the management of CML. Ann Hematol. 2015;94(S2):141-7.

9. Calmette A, Saenz A, Costil L. Effects du venin de cobra sur les greffes cancereuses et sur le cancer spontane (adeno-carcinome) de la souris. C R Acad Sci. 1933;197:205-17.

10. Rodrigues RS, Izidoro LFM, de Oliveira RJ, Sampaio SV, Soares AM, Rodrigues VM. Snake venom phospholipases A2: a new class of antitumor agents. Protein Pept Lett. 2009;16(8):894-8.

11. Costa TR, Burin SM, Menaldo DL, de Castro FA, Sampaio SV. Snake venom Lamino acid oxidases: an overview on their antitumor effects. J Venom Anim Toxins Incl Trop Dis. 2014;20(1):23.

12. Gutiérrez JM, Lomonte B. Phospholipases A2: unveiling the secrets of a functionally versatile group of snake venom toxins. Toxicon. 2013;62:27-39.

13. Khunsap S, Khow O, Buranapraditkun S, Suntrarachun S, Puthong S, Boonchang S. Anticancer properties of phospholipase A2 from Daboia siamensis venom on human skin melanoma cells. J Venom Anim Toxins Incl Trop Dis. 2016;22(1) [cited 2018 Sep 23].

14. Chwetzoff S, Tsunasawa S, Sakiyama F, Ménez A. Nigexine, a phospholipase A2 from cobra venom with cytotoxic properties not related to esterase activity. Purification, amino acid sequence, and biological properties. J Biol Chem. 1989;264(22):13289-97.

15. Kini RM. Structure-function relationships and mechanism of anticoagulant phospholipase A2 enzymes from snake venoms. Toxicon. 2005;45(8):1147-61.

16. Schaloske RH, Dennis EA. The phospholipase A2 superfamily and its group numbering system. Biochim Biophys Acta. 2006;1761(11):1246-59.

17. de Moura AA, Kayano AM, Oliveira GA, Setúbal SS, Ribeiro JG, Barros NB, et al. Purification and biochemical characterization of three Myotoxins from Bothrops mattogrossensis Snake venom with toxicity against Leishmania and tumor cells. Biomed Res Int. 2014;2014:1-13.

18. Prinholato da Silva C, Costa TR, Paiva RMA, Cintra ACO, Menaldo DL, Antunes LMG, et al. Antitumor potential of the myotoxin BthTX-I from Bothrops jararacussu snake venom: evaluation of cell cycle alterations and death mechanisms induced in tumor cell lines. J Venom Anim Toxins Incl Trop Dis. 2015;21:44.

19. Santos-Filho NA, Silveira LB, Oliveira CZ, Bernardes CP, Menaldo DL, Fuly AL, et al. A new acidic myotoxic, anti-platelet and prostaglandin 12 inductor phospholipase A2 isolated from Bothrops moojeni snake venom. Toxicon. 2008;52(8):908-17.

20. Costa TR, Menaldo DL, Oliveira CZ, Santos-Filho NA, Teixeira SS, Nomizo A, et al. Myotoxic phospholipases a(2) isolated from Bothrops brazili snake venom and synthetic peptides derived from their $\mathrm{C}$-terminal region: 
cytotoxic effect on microorganism and tumor cells. Peptides. 2008;29(10): 1645-56.

21. Gebrim LC, Marcussi S, Menaldo DL, de Menezes CSR, Nomizo A, Hamaguchi A, et al. Antitumor effects of snake venom chemically modified Lys49 phospholipase A2-like BthTX-I and a synthetic peptide derived from its C-terminal region. Biologicals. 2009:37(4):222-9.

22. Roberto PG, Kashima S, Marcussi S, Pereira JO, Astolfi-Filho S, Nomizo A, et al. Cloning and identification of a complete cDNA coding for a bactericidal and antitumoral acidic phospholipase A2 from Bothrops jararacussu venom. Protein J. 2004:23(4):273-85.

23. Lomonte B, Angulo Y, Calderón L. An overview of lysine-49 phospholipase A2 myotoxins from crotalid snake venoms and their structural determinants of myotoxic action. Toxicon. 2003;42(8):885-901.

24. Lomonte B, Rangel J. Snake venom Lys 49 myotoxins: from phospholipases a(2) to non-enzymatic membrane disruptors. Toxicon. 2012;60(4):520-30.

25. Marcussi S, Stábeli RG, Santos-Filho NA, Menaldo DL, Silva Pereira LL, Zuliani JP, et al. Genotoxic effect of Bothrops snake venoms and isolated toxins on human lymphocyte DNA. Toxicon. 2013;65:9-14.

26. Kang TS, Georgieva D, Genov N, Murakami MT, Sinha M, Kumar RP, et al. Enzymatic toxins from snake venom: structural characterization and mechanism of catalysis. FEBS J. 2011;278(23):4544-76.

27. Marcussi S, Santos PRS, Menaldo DL, Silveira LB, Santos-Filho NA, Mazzi MV, et al. Evaluation of the genotoxicity of Crotalus durissus terrificus snake venom and its isolated toxins on human lymphocytes. Mutat Res. 2011; 724(1-2):59-63.

28. Lomonte B, Gutiérrez JM, Furtado MF, Otero R, Rosso JP, Vargas O, et al. Isolation of basic myotoxins from Bothrops moojeni and Bothrops atrox snake venoms. Toxicon. 1990;28(10):1137-46.

29. Mosmann T. Rapid colorimetric assay for cellular growth and survival: application to proliferation and cytotoxicity assays. J Immunol Methods. 1983;65(1-2):55-63.

30. Riccardi C, Nicoletti I. Analysis of apoptosis by propidium iodide staining and flow cytometry. Nat Protoc. 2006;1 (3):1458-61.

31. Mashima T, Seimiya H, Tsuruo T. De novo fatty-acid synthesis and related pathways as molecular targets for cancer therapy. Br J Cancer. 2009;100(9): 1369-72.

32. Montecucco C, Gutiérrez JM, Lomonte B. Cellular pathology induced by snake venom phospholipase A2 myotoxins and neurotoxins: common aspects of their mechanisms of action. Cell Mol Life Sci. 2008;65(18): 2897-912.

33. Lomonte B, Angulo Y, Moreno E. Synthetic peptides derived from the Cterminal region of Lys 49 phospholipase A2 homologues from viperidae snake venoms: biomimetic activities and potential applications. Curr Pharm Des. 2010;16(28):3224-30.

34. Praznikar ZJ, Petan T, Pungercar J. A neurotoxic secretory phospholipase A2 induces apoptosis in motoneuron-like cells. Ann N Y Acad Sci. 2009;1152: 215-24.

35. Yanovich S, Hall RE, Weinert C. Resistance to natural killer cell-mediated cytolysis by a pleiotropic drug-resistant human erythroleukemia (K562-R) cell line. Cancer Res. 1986;46(9):4511-5.

36. Donato NJ, Wu JY, Stapley J, Gallick G, Lin H, Arlinghaus R, et al. BCR-ABL independence and LYN kinase overexpression in chronic myelogenous leukemia cells selected for resistance to STI571. Blood. 2003;101(2):690-8.

37. Cioe L, McNab A, Hubbell HR, Meo P, Curtis P, Rovera G. Differential expression of the globin genes in human leukemia $\mathrm{K} 562(\mathrm{~S})$ cells induced to differentiate by hemin or butyric acid. Cancer Res. 1981;41(1):237-43.

38. Bueno-da-Silva AEB, Brumatti G, Russo FO, Green DR, Amarante-Mendes GP. Bcr-Abl-mediated resistance to apoptosis is independent of constant tyrosine-kinase activity. Cell Death Differ. 2003;10(5):592-8.

39. Rakshit S, Mandal L, Pal BC, Bagchi J, Biswas N, Chaudhuri J, et al. Involvement of ROS in chlorogenic acid-induced apoptosis of Bcr-Abl+ CML cells. Biochem Pharmacol. 2010;80(11):1662-75.

40. Youle RJ, Strasser A. The BCL-2 protein family: opposing activities that mediate cell death. Nat Rev Mol Cell Biol. 2008;9(1):47-59.

41. Amarante-Mendes GP, Finucane DM, Martin SJ, Cotter TG, Salvesen GS, Green DR. Anti-apoptotic oncogenes prevent caspase-dependent and independent commitment for cell death. Cell Death Differ. 1998;5(4): 298-306.

42. Chipuk JE, Moldoveanu T, Llambi F, Parsons MJ, Green DR. The BCL-2 family Reunion. Mol Cell. 2010;37(3):299-310.
43. Parsons MJ, Green DR. Mitochondria in cell death. Essays Biochem. 2010;47: 99-114.

44. Pereira WO, Amarante-Mendes GP. Apoptosis: a Programme of cell death or cell disposal?: a Programme of cell death or cell disposal? Scand I Immunol. 2011;73(5):401-7.

45. Thomas CN, Berry M, Logan A, Blanch RJ, Ahmed Z. Caspases in retinal ganglion cell death and axon regeneration. Cell Death Discovery. 2017; 3(3):17032.

46. Mora R, Valverde B, Díaz C, Lomonte B, Gutiérrez JM. A Lys49 phospholipase a(2) homologue from Bothrops asper snake venom induces proliferation, apoptosis and necrosis in a lymphoblastoid cell line. Toxicon. 2005;45(5): $651-60$.

47. Chen Y-J, Liu W-H, Kao P-H, Wang J-J, Chang L-S. Involvement of p38 MAPK- and JNK-modulated expression of BCl-2 and Bax in Naja nigricollis CMS-9-induced apoptosis of human leukemia K562 cells. Toxicon. 2010; 55(7):1306-16.

48. Cummings BS, McHowat J, Schnellmann RG. Phospholipase A(2)s in cell injury and death. J Pharmacol Exp Ther. 2000;294(3):793-9.

49. Panini SR, Yang L, Rusinol AE, Sinensky MS, Bonventre JV, Leslie CC. Arachidonate metabolism and the signaling pathway of induction of apoptosis by oxidized LDL/oxysterol. J Lipid Res. 2001;42(10):1678-86.

50. Chethankumar M, Srinivas L. PID15, a novel $6 \mathrm{kDa}$ secreted peptide, mediates Naja naja venom phospholipase $\mathrm{A}_{2}$ induced apoptosis in isolated human peripheral lymphocytes. J Biomed Sci. 2014;21:66.

\section{Ready to submit your research? Choose BMC and benefit from:}

- fast, convenient online submission

- thorough peer review by experienced researchers in your field

- rapid publication on acceptance

- support for research data, including large and complex data types

- gold Open Access which fosters wider collaboration and increased citations

- maximum visibility for your research: over $100 \mathrm{M}$ website views per year

At BMC, research is always in progress.

Learn more biomedcentral.com/submissions 